The Geneva Papers on Risk and Insurance, 18 (No. 68, July 1993), 233-236

\title{
Reflections on the Twentieth Anniversary of The Geneva Association
}

\author{
by Reimer Schmidt*
}

The notion that an industry should support an Association, dedicated to the development of research in those subjects which affect its own professional business activity, is as significant today as it was when this Association was formed. In addition, however, I believe that the origin of the Geneva Association was based on a clear perception of further development. Therefore, on the occasion of its 20th Anniversary, I would like to contribute some reflections on the relationship between practical activity and scientific work.

The advance of economic theory, in the years immediately after the Second World War, has, since then, been reinforced and expanded. During this period, business administration has become a subject of general education and has significantly developed the methodology of practical business management.

The subjects originally covered by business studies ${ }^{1}$ courses which included, amongst others, accountancy and the original organization and management studies, have developed into separate sciences and extended into other areas, including the study of insurance, which in my opinion has been particularly fostered in Germany. The extent and the strength of the links between economic research and practical application vary from country to country. The insurance industry has always been interested in more practically based investigations and thus ensured that the study of insurance has developed from being a branch of banking studies into a study in its own right.

Contemplating business studies, one is mindful of the study of organization just as much as marketing and distribution. In the insurance industry, because of the broad spectrum of classes of business underwritten and the necessity to rationalize the distribution, the study of organization has great practical importance. The requirements of the markets have clearly led, over the years, to the adaptation of old structures and the emergence of new structures. The practical testing of theoretical observations and the theoretical validation of opportune practical innovations are the hallmarks of progress.

Another factor in consideration of the development of business organization in the insurance industry is the computer, which has led to greater intellectual mastery over the problem of volume. Whilst that differs from class to class, according to the type of insurance,

* Honorary President of the Geneva Association.

${ }^{1}$ In this paper, the boundary between economic theory and business studies is not strictly drawn. 
and is characterized by the time scale of the processing of the insurance cover, claims administration and the financial results depending on the classes of risk and the groups insured, it extends far beyond the basic working procedures and statistical techniques which formed the standard know-how of the previous generation.

Similar considerations come to mind for those areas concerned with investment management. All these are areas where industry demands solutions from research - which often must first of all be undertaken - and expects the results of such research not only to be understandable but also to have the widest possible practical application. Both sides must live with this tension. The development of the insurance theory leads to the conclusion that this tension is beneficial.

In general, however, the relationship between theory and practice is usually more relaxed, as the conclusions of business theory are designed to enhance the efficiency of business operations, so that taken as a whole, they tend not to differ fundamentally from management's own objectives. In any case, it would seem that the concepts and systems of evaluation used in economic theory and in the practice of insurance. But this comparison should not always be seen as a positive feature of business theory.

One of the basic premises for the formation of the Geneva Association was the perception of an unfortunate rift, in theory and in application, between enonomics and the practice of insurance. The insurance industry felt under obligation to provide economists with factual material and to explain the context. At the same time it had to question economists whether probability of results of direct practical relevance would be much smaller than those from business studies.

On the other hand, the exercise of thinking along these lines represented - and still represents - a particular challenge for the insurance industry, because in the wide field of economic theory, with its emphasis on the common good, chains of thought had - and have - to be considered, which not only touch directly upon the essence of insurance, but can also further its general development. The Geneva Association has therefore rightly seen this as an area of special responsibility, to the pursued not so much by studies of its own as by encouraging research by others. The Association's endeavors in this area have in the past been characterized by the great variety of their publications and lectures.

In the area of the Treaty of Rome, the endless discussion of Competition Law in the insurance industry has broadened the basis of the theory of competition with its varying points of emphasis and this must be the subject of further thought. The insurance market is amongst those were information is incomplete and this is exacerbated, in the 'mass risk' business, by the problems of the insureds' limited ability and willingness to provide information. Incompleteness of information poses additional questions and the varying standards of national monopoly laws will necessitate further consideration, as will the problems of derogation therefrom. In this connection, consideration must be given to the fact that, in the insurance industry, the mass risks business not only poses problems for competition policy but also simultaneously draws attention to the valid need for protection of the consumer. The consumer protection organizations are not, however, prepared to accept the argument that competition itself provides the optimal protection in relation to conditions and prices and, in opposition to the aforesaid thesis of competition policy, they propound the axiom, established in the welfare economy, of additional consumer protection regulations; this can be counter-productive. Herein lies food for thought for another generation. 
Economic research specific to the insurance industry also continues to require encouragement by the Association. It is scarcely necessary to add that the industry has, from time immemorial, counted the calculus of probability amongst its basic instruments and its analysis and development (for example in the field of Decision Theory) has been, and will continue to be, within the ambit of the Association's work and observation.

In the last two decades, the phenomenon of risk has progressively invaded scientific studies. In part influenced by existential philosophy and the impact of catastrophes as reported by the media, the populace in our countries has become more risk conscious and risk sensitive. Science has recognized that 'Risk' not only describes an externally perceived situation or an objective state but, at the same time, is also reflected in the mind and in comparison with 'normal' situations of everyday life. The 'known' event will be comprehended as the opposite of the 'random' event. Here the findings of economics, psychology and sociology come together as a group of scientists under the Munich economist Holzheu recently demonstrated. For a number of years now, and with the active participation of its Secretary General, Prof. Orio Giarini, the Geneva Association has been fundamentally concerned with the concept of risk. Coincidentally, in these researches mathematical methods also have a role to play in the field of measurement of claims frequencies and consequently also in the tarification of risks which is of special principles, non-life insurance. The application of scientific principles will make the practical use by insurers of information, risk transfer and risk management more effective and thereby, at the same time, circumstances permitting, serve to reduce the cost of insurance. Because of this, the instrument of risk management has developed particularly in the actual business setting and, as personified by the risk manager, has gained exceptional practical significance. It should also be mentioned here that a group of theoretical and practical mathematical economists (economic mathematicians) has, for some years, regularly met together and conducted a creative exchange of ideas having insurance implications.

Another economic problem that requires analysis is the consideration of the goals and function of insurance in the service economy - another aspect particularly instigated by Giarini - and this has led to effective further development. A number of studies, here only briefly outlined, simultaneously play a role of defining the concept of insurance more precisely, by describing its various aspects and its 'essence', an interesting question in itself which really calls for a scientific stocktaking.

The stimulation of these ideas should not be taken to mean that the Geneva Association aimed to carry out and publish its own research, but rather to be recognized as the natural partner in the dialogue with the scientists and at the same time to provide them with a suitable platform.

The Association's constitution placed the promotion of economic studies relating to insurance and also the role of insurance in economic and business studies at the center of its activities. In an age of multi-disciplinary research this does not impose any limitation on its scope, although specialist legal studies for example would fall outside its purview. However, time and again when examining legal facts and judgements, one has to consider the economic background to legal directives, contractual agreements and even judicial decisions. In this connection, the questions that have to be addressed go much further than those posed by an economic analysis of the Law, which ignores their scientific significance. 
The Treaty of Rome, itself an International Agreement, is seeking to establish, by legislative means (above all, through conventions of international laws, EC Secondary Law and by legal opinions of the European Court of Justice), a distinctive overall economic regime that is still in the course of development. This further stretches the ambit of the Geneva Association for the Study of Insurance Economics; notwithstanding the fact that large variety of institutes at national and university levels, as well as independent researchers, are occupied with the specialized questions of the EC. Without going into particular questions, it is also clear that the essential points treated by the Directives are not fully comprehensible legally, nor can they be adapted, unless the economic aims and fundamentals are constantly borne in mind and adequate consideration is given to the nexus between legal and economic issues. Regarding these essential points, one has in mind e.g. prohibition of discrimination, freedom of contract, the concepts of Liberalization and Harmonization of Laws and Community Competition Law.

On the occasion of the 20th Anniversary of the Geneva Association, it has been my aim to express some considerations arising from a long period of friendly and exceptionally stimulating association, together with my good wishes for its future activity. There is still much to do. 